\title{
Perception towards Examination and Students' Performance in Three Modes of Quizzes
}

\author{
Leemarc C. Alia \& Arlene C. Dolotallas, PhD \\ Mindanao State University at Naawan \\ 9023 Naawan, Misamis Oriental \\ Philippines
}

\begin{abstract}
Students enter in the classroom with different sets of behaviors, learning styles and attitudes towards learning. This study dealt to find out the relationship on the students' perception towards examination and students' performance in the three modes of quizzes namely; announced, immediate and unannounced quizzes. The subjects of the study were the 48 education students who were enrolled in Environmental Science (EdSc 140) of Mindanao State University at Naawan. The study used survey questionnaires on the perception towards examination, and test questionnaires for quizzes. This study utilized a quantitative-descriptive correlational research design. Data were analyzed and organized through percentage, mean and chi-square test. Analysis of variance showed significant difference on the students' performance in the three modes of quizzes. Chi-square test result showed a significant relationship between the students' perception towards examination and their performance in three modes of quizzes as shown in the p-value of 4.9E-16. Moreover, there was no significant relationship between the students' performance in the three modes of quizzes and their achievement scores in Environmental Science with a p-value of 0.5142. Based on the results, this study concluded that perception towards examination can affect the students' performance in the three modes of quizzes. This implies that students performed better in announced compared to unannounced and immediate quizzes. They like quizzes that are scheduled and when there is ample time given for them to prepare. For further study, comparison of three modes of quizzes can be done with the use of different strategies and correlate it to their performance and they may include the gender differences of students to find out which mode of quiz does a male and female performed better.
\end{abstract}

Keywords: Perception, Performance, Modes of quizzes and Examination

\section{Introduction}

Education is a long and continuous process that involves both learner and educator. It's primarily concerned with the students' performance and structural measurements that has a poor rapport with the curriculum and instruction without entertaining the effect of the program on the students (Kallick and Wilson, 2011).In the classroom, every learner aspires to acquire knowledge and develop analytical skills. He has his own behavior, capabilities, attitudes and learning style which are different from his peers. All these learning outcomes have to be measured through evaluation. Evaluation determines the progress and performance of the students in the classroom in terms of quantity and quality of learning. According to Nem Singh and Padilla (2009) evaluation is the bringing together from different sources of all forms of information on student performance. Evaluation of students will allow teachers to identify the strength and weaknesses of students. Evaluation is classified according to the period in which it is conducted. Formative evaluation is conducted during instruction. It is used to monitor students' progress and obtain ongoing feedback about strengths and weaknesses of both the students and the teachers. Summative evaluation occurs at the end of unit, course or term. It aims to assess and determine the effectiveness of an educational program. Diagnostic evaluation is administered prior to instruction, it aims to determine the starting point and identify needed prerequisite skills and learning difficulties (Del Socorro et al; 2011).

The teachers give quizzes or short test to obtain immediate feedback if the students really understood the imparted lesson. Quiz is a vital part of measuring teaching and learning process because it allows students to see their own progress and performance in school. Quizzes are classified according to the period in which it will be conducted. Multiple quizzes are reasonable extrinsic motivators for learning. Giving regular quizzes encourages regular study and better overall performance. With this, quizzes can be used to test students' retention of course materials. 
It also indicates that quizzes helped students to keep up with the course material (Azarlosa and Renner, 2006).Airasian (2005), states that the test that is given immediately after completing the instruction provides students the opportunity to review study and reflect on the instruction before being tested. On the other hand, Azarlosa and Renner (2006) found that in announced and unannounced quizzes students gained almost twenty percent points on the quiz sources when the quizzes were announced and reported and after reading the assignment articles more thoroughly, and if the students expected the quiz. The study showed that announced quizzes can cause students to study more. Also, announced quizzes increased attendance on the dates that the instructor gives quizzes. Kamuche (2007) revealed on his study that using unannounced quizzes and anonymous are better long-term memory, than simply hearing, memorizing or reading about a concept. It had an impact on students' performance compared to announced quizzes.

Alia and Manait (2013), showed on their comparative study on the performance of grade seven students in three modes of quizzes revealed that students perform better in immediate compared to unannounced and announced quizzes since, the topics are still fresh on the mind. Teachers administer different modes of quiz to measure the learning capacity of students and to discover which mode of quiz they had administered in a more effective way. Some students are good in announced quiz but not in immediate and unannounced quiz. There are students who performed better in immediate quiz compared to announced and unannounced quiz. Also, there are students who do much better in unannounced quiz rather than announced and immediate quiz.It is in this premise that the current study was conducted to explore the relationship of perception towards examination and the students' performance in the three modes of quizzes in Environmental Science. The study also aims to evaluate if it has an effect to students and help them improve their performance.

\subsection{Statement of the problem}

This study tried to find out the relationship between the perceptions towards examination and the students' performance in the three modes of quizzes. This study sought to answer the following questions:

1. What is the students' perception towards examination when grouped to:

a. Announced quizzes

b. Immediate quizzes

c. Unannounced quizzes?

2. What is the students' performance in the three modes of quizzes when grouped to:

a. Announced quizzes

b. Immediate quizzes

c. Unannounced quizzes?

3. What is the students' achievement score in Environmental Science when grouped to:

a. Prelim Examination

b. Midterm Examination

c. Final Examination?

4. Is there a significant difference on the students' performance when grouped to three modes of quizzes?

5. Is there a significant relationship between the students' perception towards examination and performance in the three modes of quizzes?

6. Is there a significant relationship between the students' performance in the three modes of quizzes and achievement score in Environmental Science?

\section{Null Hypotheses}

Ho: There is no significant difference on the students' performance when grouped to the three modes of quizzes

$\mathbf{H o}_{2}$ : There is no significant relationship between the students' perception towards examination and their performance in the three modes of quizzes

Ho3: There is no significant relationship between the students' performance in the three modes of quizzes and their achievement score in Environmental Science

\subsection{Scope and limitations of the study}

This study was limited only to the forty-eight (48) Education students of Mindanao State University at Naawan who were enrolled in Environmental Science (EdSc 140) for the A.Y. 2016-2017 under the researchers' advisory. The study focused on the students' perception towards examination and their performance in the three modes of quizzes. This study conducted in five (5) months. 


\subsection{Definition of terms}

The following terms are defined to clarify the terms used in the study;

Announced quiz is a mode of quiz that is properly scheduled or announced by the teacher.

Achievement score refers to the scores obtained by the students during examination.

Environmental Science refers to the subject from which the data were gathered.

Final Examination is a test given after unannounced quizzes was implemented

Fourth Year refers to the year level of the respondents of the study.

Immediate quiz is a mode of quiz that the teacher gives right after the discussion.

Midterm Examination is a test given after immediate quizzes was implemented

Mindanao State University at Naawan refers to the area where the study was conducted.

Perception refers to the respondents' view or idea about examination.

Performance is the scores obtained by the students in the three modes of quizzes.

Prelim examination is a test given after announced quizzes was implemented

Pre-Post assessment an assessment given before and after the three modes of quiz is implemented

Quiz it is a short test to assess students learning and is composed of 10 items.

Unannounced quiz refers to mode of quiz that the teacher surprisingly administerswithout advance notification

\section{Materials and Methods}

\subsection{Research design}

This study used quantitative correlational research design in determining the significant differences and relationship in the performance of students in the three modes of quizzes in Environmental Science. Data were transmitted to numerical figure to undergo statistical analysis.

\subsection{Subject of the study}

The respondents of the study were the education students enrolled in (EdSc 140) Environmental Science in Mindanao State University at Naawan during the first semester A.Y. 2016-2017. There were forty-eight (48) students involved in the study. Twenty-eight (28) Bachelor of Elementary Education major in Science and Health, eighteen (18) Bachelor of Secondary Education major in General Science and two (2) Bachelor of Secondary Education major in Biology included in the study.Mindanao State University at Naawan is located at Poblacion, Naawan Misamis Oriental with neighboring barangays such as Linangkayan, Maputi, Don Pedro, Patag, Mapulog, Tagbalogo, Lubilan, Mat-I and Tuburan (figure 2).

\subsection{Data gathering procedure}

After the identification of the study area and the respondents of the study, a letter of permission was sent to the Vice Chancellor for Academic Affairs through the Dean of the College of Education and Social Sciences and to the Department Chairperson of the Elementary and Secondary Education for the conduct of the study during the first semester A.Y 2016-2017 in the subject Environmental Science (EdSc 140). Then, the researcher distributed the survey questionnaire on perception of students towards examination which was given before and after the implementation of the study. Afterwards, implementation of the three modes of quizzes was given. Each mode of quiz was randomly selected through draw lots on which was administered first on prelim, midterm and finals. Five (5) announced quizzes were administered by the researcher to all students during the prelim. Another five (5) set of immediate quizzes was given in the midterm period. Moreover, five (5) unannounced quizzes were also administered in the finals and determine their performance in the three modes of quizzes. Achievement scores were also gathered after the three examinations were given. The topics that the teacher discussed were based on the lessons in the course syllabus content of the subject Environmental Science.

\subsection{Instrument used in the study}

The instruments used in the study were the survey questionnaire on the perception towards examination which is composed of fifteen (15) statements where students need to check the 4 scales (SA, A, D, \& SD) strongly agree, agree, disagree and strongly disagree that were described and how they felt about the statements and the test questionnaires for the three modes of quizzes. 
The three modes of quizzes were composed of five (5) questions each for the announced, immediate and unannounced quizzes. The achievement score was also taken from their prelim, midterm and final examination. Below are the table used in interpreting the data of the study.

\section{Results}

\subsection{Students' perception towards examination when grouped to announced, immediate and unannounced} quizzes

\subsubsection{Students' perception towards examination when grouped to announced quizzes}

Table 3 shows the mean distribution on the students' perception towards examination when grouped to announced quizzes. Students' response strongly agree on I like exam when the teacher announced it (item 2) with an average mean of 3.63, I prefer to have an exam weekly (item 4) with an average mean of 3.51, and I get high score when there is time for me to prepare for exam (item 5) with an average mean of 3.49. The students also agree on a scheduled exam helps me get a high score (item 1) with an average mean of 2.5 , and I prefer to take a delayed exam (item 3 ) with an average mean of 2.77 . The overall mean is 3.18 which means agree.

Table 3. Mean distribution on the students' perception towards examination when grouped to announced quizzes

\begin{tabular}{|c|c|c|c|c|c|c|c|}
\hline \multirow{2}{*}{$\begin{array}{l}\text { Item } \\
\\
1\end{array}$} & \multirow{2}{*}{$\begin{array}{l}\text { Statement } \\
\text { A scheduled exam helps me } \\
\text { get a high score }\end{array}$} & \multicolumn{2}{|c|}{$\begin{array}{l}\text { Pre-assessment } \\
\text { Mean Description }\end{array}$} & \multicolumn{2}{|c|}{$\begin{array}{l}\text { Post-assessment } \\
\text { Mean } \\
\text { Description }\end{array}$} & \multirow{2}{*}{$\begin{array}{l}\text { Ave. } \\
\text { Mean } \\
2.5\end{array}$} & \multirow{2}{*}{\begin{tabular}{|l|} 
Description \\
Agree
\end{tabular}} \\
\hline & & 2.23 & Disagree & 2.77 & Agree & & \\
\hline 2 & $\begin{array}{l}\text { I like exam when the teacher } \\
\text { announced it }\end{array}$ & 3.46 & $\begin{array}{l}\text { Strongly } \\
\text { agree }\end{array}$ & 3.77 & $\begin{array}{l}\text { Strongly } \\
\text { agree }\end{array}$ & 3.62 & $\begin{array}{l}\text { Strongly } \\
\text { agree }\end{array}$ \\
\hline 3 & I prefer to take delayed exam & 2.85 & Agree & 2.69 & Agree & 2.77 & Agree \\
\hline 4 & $\begin{array}{l}\text { I prefer to have a exam } \\
\text { weekly. }\end{array}$ & 3.42 & $\begin{array}{l}\text { Strongly } \\
\text { agree }\end{array}$ & 3.60 & $\begin{array}{l}\text { Strongly } \\
\text { agree }\end{array}$ & 3.51 & $\begin{array}{l}\text { Strongly } \\
\text { agree }\end{array}$ \\
\hline 5 & $\begin{array}{l}\text { I get high scores when there is } \\
\text { time for me to prepare for } \\
\text { exam. }\end{array}$ & 3.40 & $\begin{array}{l}\text { Strongly } \\
\text { agree }\end{array}$ & 3.58 & $\begin{array}{l}\text { Strongly } \\
\text { agree }\end{array}$ & 3.49 & $\begin{array}{l}\text { Strongly } \\
\text { agree }\end{array}$ \\
\hline \multicolumn{2}{|c|}{ Overall mean } & 3.07 & Agree & 3.28 & $\begin{array}{l}\text { Strongly } \\
\text { agree }\end{array}$ & 3.18 & Agree \\
\hline
\end{tabular}

\subsubsection{Students' perception towards examination when grouped to immediate quizzes}

Table 4 displays the mean distribution on the students' perception towards examination when grouped to immediate quizzes. Students' respond strongly agree on an exam at the end of the discussion tests my understanding to the topic discussed (item 3) with an average mean of 3.36. Most of them also respond agree on I prefer to have an exam right after the discussion (item 1) with an average mean of 3.10. I get high score when exam is given at the end of the lesson (item 2) with an average mean of 2.95. Immediate exam motivates me to take down notes during discussion (item 5) with an average mean of 3.20. Students disagree in I like exam at the middle of the discussion (item 4 ) with an average mean of 2.15 . The overall mean is 2.95 which means agree. 
Table 4. Mean distribution on the students' perception towards examination when grouped to immediate Quizzes

\begin{tabular}{|c|l|l|l|l|l|l|l|l|}
\hline Item & Statements & \multicolumn{2}{|l|}{$\begin{array}{l}\text { Pre-assessment } \\
\text { Mean }\end{array}$} & \multicolumn{2}{l|}{$\begin{array}{l}\text { Post- assessment } \\
\text { Mean }\end{array}$} & \multicolumn{2}{l|}{$\begin{array}{l}\text { Aves } \\
\text { Mean }\end{array}$} \\
\hline 1 & $\begin{array}{l}\text { I prefer to have an exam right after the } \\
\text { discussion. }\end{array}$ & 3.02 & Agree & 3.17 & Agree & 3.10 & Agree \\
\hline 2 & $\begin{array}{l}\text { I get high score when exam is given at } \\
\text { the end of the lesson. }\end{array}$ & 2.85 & Agree & 3.04 & Agree & 2.95 & Agree \\
\hline 3 & $\begin{array}{l}\text { An exam at the end of the discussion } \\
\text { tests my understanding to the topic } \\
\text { discussed. }\end{array}$ & 3.31 & $\begin{array}{l}\text { Strongly } \\
\text { agree }\end{array}$ & 3.40 & $\begin{array}{l}\text { Strongly } \\
\text { agree }\end{array}$ & 3.36 & $\begin{array}{l}\text { Strongly } \\
\text { agree }\end{array}$ \\
\hline 4 & $\begin{array}{l}\text { Ilike exam at the middle of the } \\
\text { discussion. }\end{array}$ & 2.10 & $\begin{array}{l}\text { Dis- } \\
\text { agree }\end{array}$ & 2.19 & Disagree & 2.15 & Disagree \\
\hline 5 & $\begin{array}{l}\text { Immediate exam motivates me to take } \\
\text { down notes during discussion. }\end{array}$ & 3.06 & Agree & 3.33 & $\begin{array}{l}\text { Strongly } \\
\text { agree }\end{array}$ & 3.20 & Agree \\
\hline & $\quad$ Overall mean & 2.87 & Agree & 3.03 & Agree & 2.95 & Agree \\
\hline
\end{tabular}

\subsubsection{Students' perception towards examination when grouped to unannounced quizzes}

Table 5 presents the mean distribution on the students' perception towards examination when grouped to unannounced quizzes. Students express agree on I prefer to have an exam given the day before another lesson starts (item 2 with an average mean of 2.77, and I like exam related to my assignment (item 4) with an average mean of 2.02, I get high score if the exam is given before the discussion (item 3) with an average mean of 2.22, I can get high score when our teacher gives surprise exam (item 5) with an average mean of 1.98. The overall mean is 2.42 which means disagree.

Table 5. Mean distribution on the students' perception towards examination when grouped to unannounced quizzes

\begin{tabular}{|c|c|c|c|c|c|c|c|}
\hline \multirow{2}{*}{$\begin{array}{l}\text { Item } \\
1\end{array}$} & \multirow{2}{*}{$\begin{array}{l}\text { Statements } \\
\text { I like surprise exam. }\end{array}$} & \multicolumn{2}{|c|}{$\begin{array}{l}\text { Pre-assessment } \\
\text { Mean Description }\end{array}$} & \multicolumn{2}{|c|}{$\begin{array}{l}\text { Post-assessment } \\
\text { Mean Description }\end{array}$} & \multirow{2}{*}{$\begin{array}{l}\text { Ave. } \\
\text { Mean } \\
2.02\end{array}$} & \multirow{2}{*}{$\begin{array}{l}\text { Description } \\
\text { Disagree }\end{array}$} \\
\hline & & 1.96 & Disagree & 2.08 & Disagree & & \\
\hline 2 & $\begin{array}{l}\text { I prefer to have a exam given the day before } \\
\text { another lesson starts. }\end{array}$ & 2.81 & Agree & 2.73 & Agree & 2.77 & Agree \\
\hline 3 & $\begin{array}{l}\text { I get high score if the quiz is given before the } \\
\text { discussion. }\end{array}$ & 2.21 & Disagree & 223 & Disagree & 2.22 & Disagree \\
\hline 4 & I like exam relate to my assignment. & 2.96 & Agree & 3.15 & Agree & 3.06 & Agree \\
\hline 5 & $\begin{array}{l}\text { I can get high scores when our teacher gives } \\
\text { surprise exam. }\end{array}$ & 1.90 & Disagree & 2.06 & Disagree & 1.98 & Disagree \\
\hline \multicolumn{2}{|c|}{ Overall mean } & 2.37 & Disagree & 2.45 & Disagree & 2.41 & Disagree \\
\hline
\end{tabular}

4.2. Students' performance on the three modes of quizes when grouped to announced, immediate and unannounced quizzes

\subsubsection{Students' performance in the three modes of quizzes when grouped to announced quizzes}

Figure 4 shows the pecentage distribution on the students' performance in the three modes of quizzes when grouped to announced quizzes. Forty percent (39.58\%) of the students have scores between 36-40 which means good, twenty-seven percent (27.08\%) of them have scores between 31-35 which means satisfactory, seventeen percent (16.67\%) of them have scores between 41-45 which means very good and seventeen percent (16.67\%) of students have scores between 26-30 which means passed respectively. 


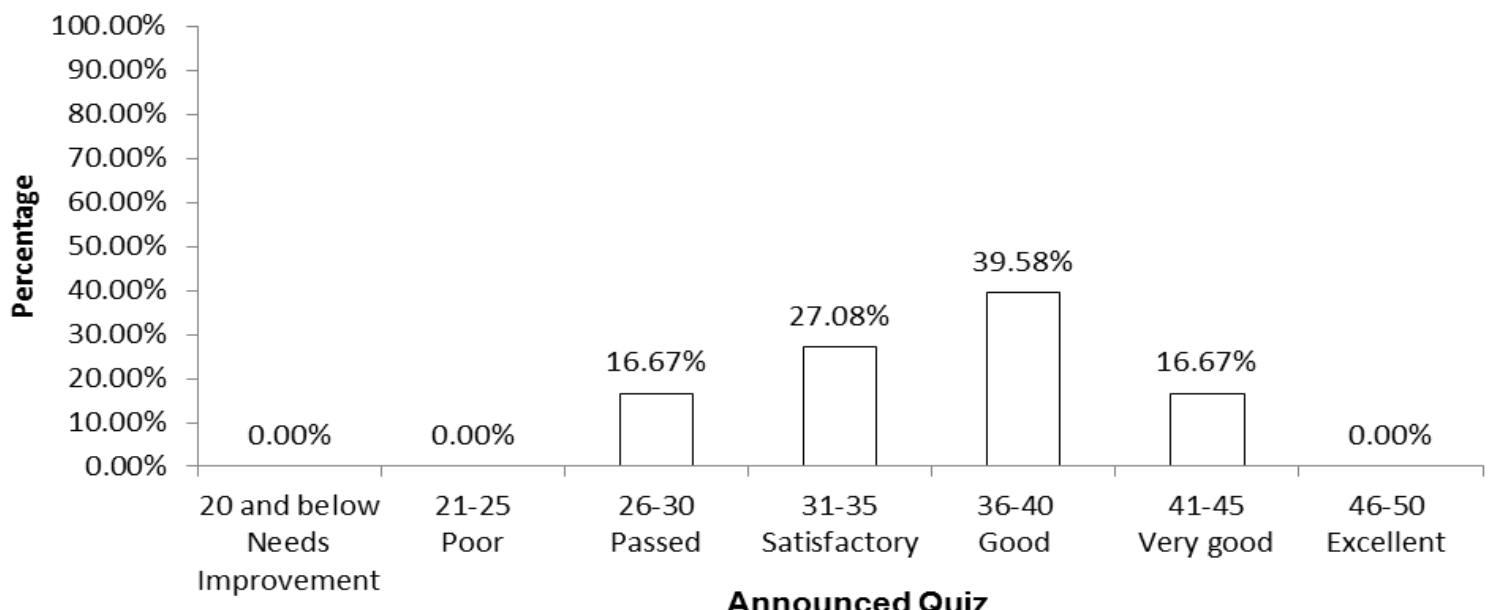

Figure 4. Percentage distribution on the students' performance in the three modes of quizzes when grouped to announced quizzes

\subsubsection{Students' performance in the three modes of quizzes when grouped to immediate quizzes}

Figure 5 displays the percentage distribution on the students performance in the three modes of quizzes when grouped to immediate quizzes. Forty percent (39.58\%) of the students have scores between 31-35 which means satisfactory, thirty eight percent $(37.50 \%)$ of them have scores between 26-30 which means passed, seventeen percent (16.67\%) have scores between 36-40 which means good, four percent (4.17\%) have scores between 21-25 which means poor and two percent $(2.08 \%)$ have scores between $41-45$ which means very good.

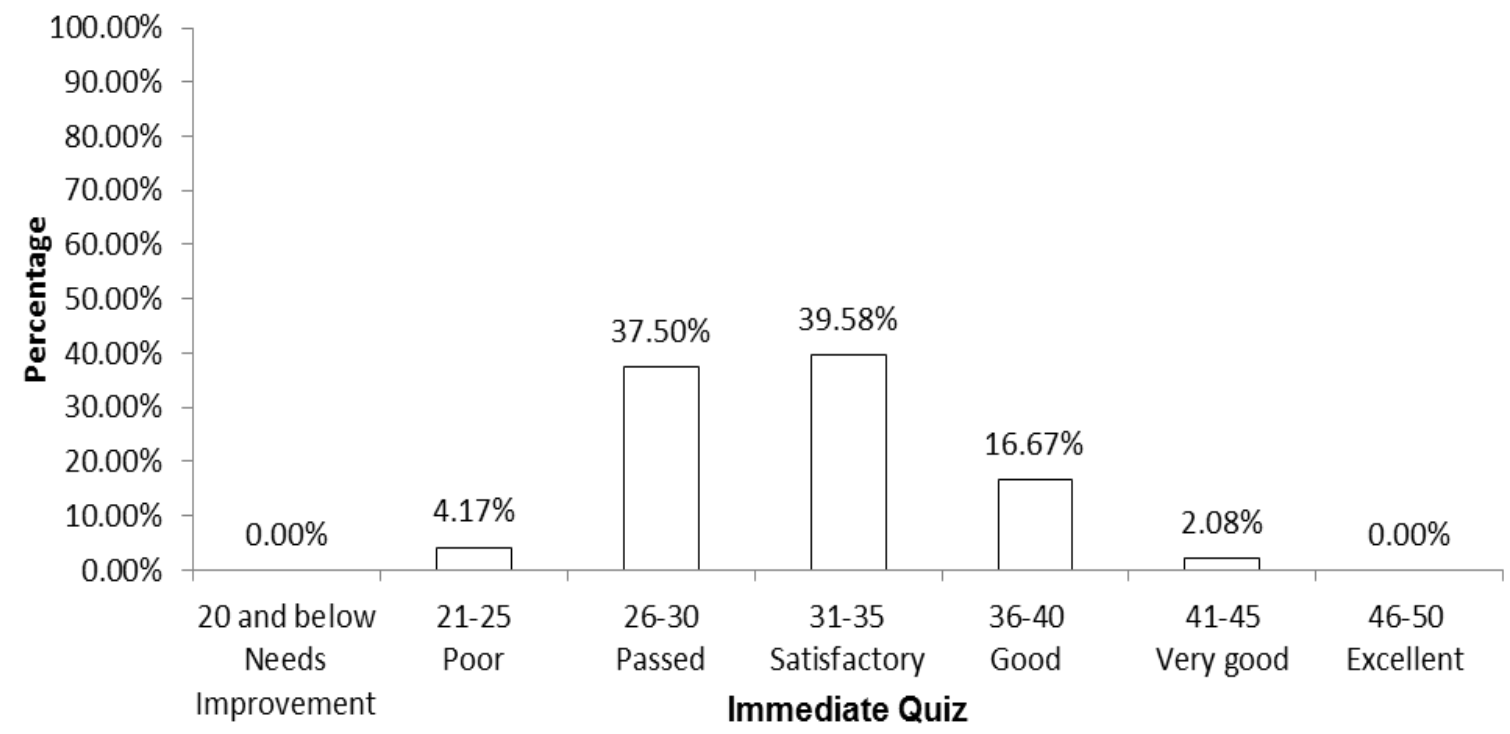

Figure 5. Percentage distribution on the students' performance in the three modes of quizzes when grouped to immediate quizzes

\subsubsection{Students' performance in the three modes of quizzes when grouped to unannounced quizzes}

Figure 6 signifies the percentage distribution on the students' performance in the three modes of quizzes when grouped to unannounced quzzes. Most (60.42\%) of the students have score between 26-30 which means passed, twenty three percent $(22.92 \%)$ of them have scores between $21-25$ which means poor, thirteen percent $(12.50 \%)$ of them have scores between 31-35 which means satisfactory and four percent (4.17\%) have scores between 3640 which means good. 


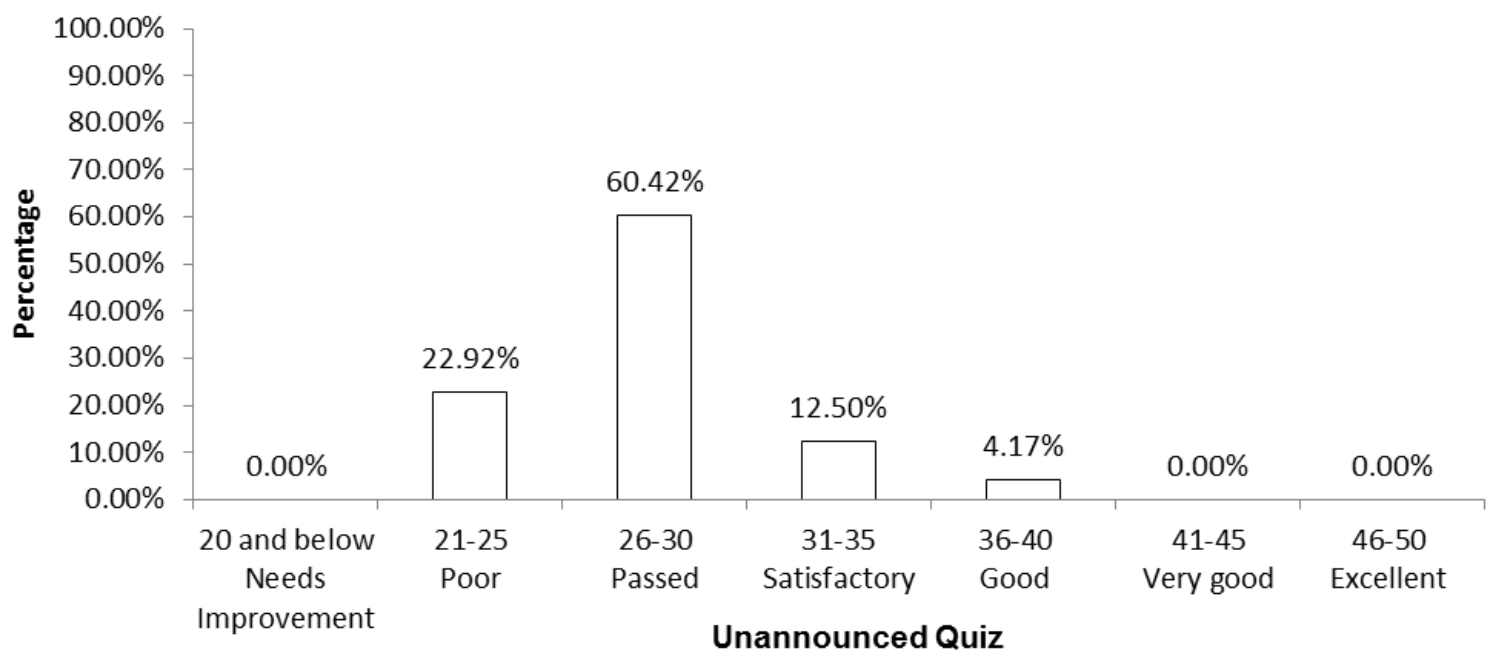

Figure 6. Percentage distribution on the students' performance in the three modes of quizzes when grouped to unannounced quizzes.

3.3. Students' achievement score in Environmental Science when grouped to prelim, midterm and final examination

\subsubsection{Students' achievement score in Environmental Science when grouped to prelim examination}

Figure 7 shows the percentage distribution on the students achievement scores in Environmental Science when grouped to prelim examination.Fifty percent (50\%) of the students have scores between 36-40 which means good, twenty seven percent $(27.08 \%)$ of them have scores between 41-45 which means very good ,thirteen percent $(12.50 \%)$ of them have scores between 31-35 which means satisfactory, four percent $(4.17 \%)$ of them have scores between 26-30 which means passed and 46-50 which means excellent, and two percent (2.08\%) of them have scores between 21-25 which means poor.

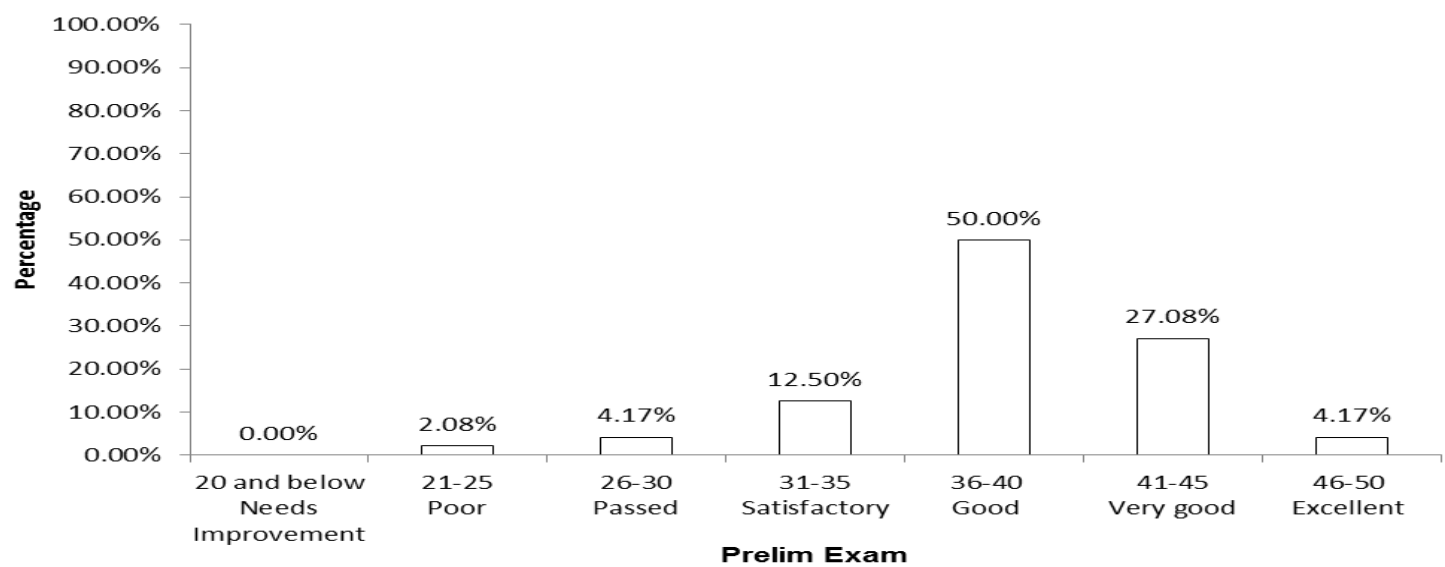

Figure 7. Percentage distribution on the students' achievement score in Environmental Science when grouped to prelim examination

\subsubsection{Students' achievement score in Environmental Science when grouped to midterm examination}

Figure 8 presents the percentage distribution on the students' achievement score in Environmental Science when grouped to midterm examination. Thirty three percent (33.33\%) of the students have scores between 26-30 which means passed, twenty nine percent $(29.17 \%)$ of them have scores 36-40 which means passed, twenty seven percent $(27.08 \%)$ of them have scores between 31-35 which means satisfactory, six percent $(6.25 \%)$ of them have scores between 21-25 which means poor and four percent (4.17\%) have scores 41-45 which means very good. 


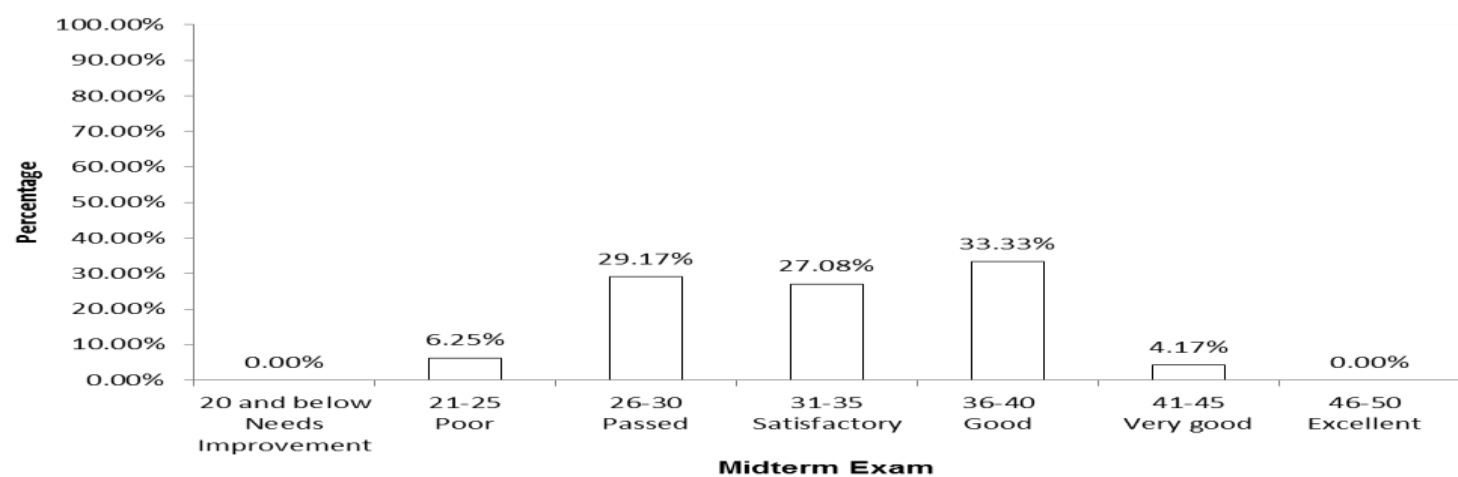

Figure 8. Percentage distribution on the students' achievement score in Environmental Science when grouped to midterm examination

\subsubsection{Students' achievement score in Environmental Science when grouped to final examination}

Figure 9 shows the percentage distribution on the students achievement score in Environmenal Science when grouped to final examination. Forty percent (39.58\%) have scores between 26-30 which means passed, thirty-five percent (35.42\%) have scores between 31-35 which means satisfactory, thirteen percent $(12.50 \%)$ of them have scores between 21-25 which means poor, ten percent (10.42\%) of them have scores between 36-40 which means good, and two percent $(2.08 \%)$ have scores 20 and below which means needs improvement.

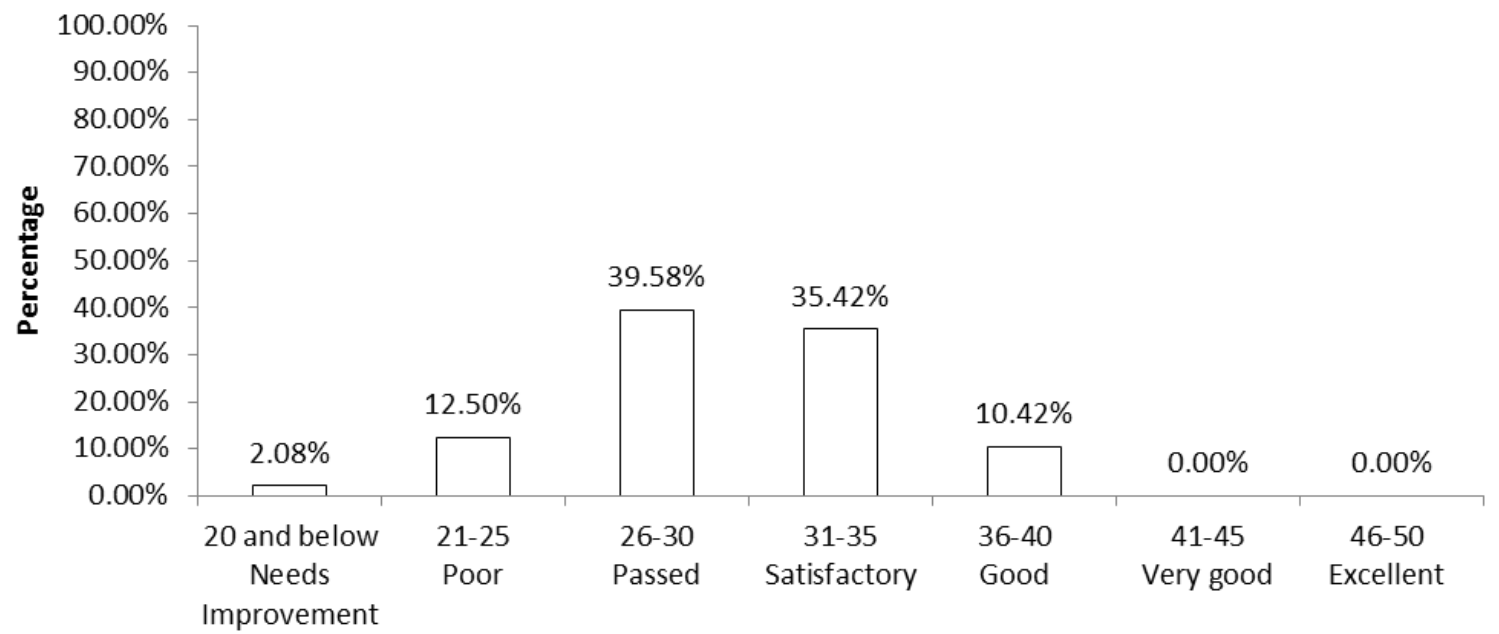

Final Exam

Figure 9. Percentage distribution on the students' achievement score in Environmental Science when grouped to final examination

\subsection{Difference on the students' performance in the three modes of quizzes}

Table 6 shows the analysis of variance test results showing the difference on the students' performance in the three modes of quizzes. It displays significant difference on the students' performance in the three kinds of quizzes since the f-value is 45.73887 and the p-value is $4.9 \mathrm{E}-16$ and that the hypothesis is rejected.

Table 6. Analysis of variance test result showing the difference on the students' performance in the three modes of quizzes

\begin{tabular}{lllllll}
\hline Variable & SS & Df & MS & F & P-value & Remarks \\
\hline Modes of Quiz & 1512.181 & 2 & 756.0903 & 45.73887 & $4.9 \mathrm{E}-16$ & significant \\
Within Groups & 2330.813 & 141 & 16.53059 & & & \\
Total & 3842.993 & 143 & & & & \\
\hline
\end{tabular}

3.5. Relationship between the students' perception towards examination and performance in the three modes of quizzes 
Table 7 presents the test result showing the relationship between the students' perception towards examination and their performance in the three modes of quizzes. It reveals significant relationship on the students' perception towards examination and the performance in the three modes of quizzes where the p-value is 0.02 lesser than the associated p-value and that the null hypothesis is rejected.

Table 7. Chi-square test result showing the relationship between the students' perception towards examination and their performance in the three modes of quizzes

\begin{tabular}{lccl}
\hline Variable & $\mathbf{X}^{2}$ & P-value & Remarks \\
\hline Perception & 4.86 & 0.0276 & significant \\
Modes of Quizzes & & & \\
\hline
\end{tabular}

With 0.05 level of significance

3.6. Relationship between the students' performance in the three modes of quizzes and achievement scores in Environmental Science

Table 8 presents the test results showing the relationship between the students' performance in the three modes of quizzes and achievement score in Environmental Science. It signifies no significant difference on the students' performance in the three modes of quizzes and achievement score in Environmental Science with a p-value of 0.5142 which is greater than 0.05 level of significance. Hence, the p-value and the null hypothesis is not rejected.

Table 8. Chi-square test result showing the relationship between the students' performance in the three modes of quizzes and their achievement score in Environmental Science

\begin{tabular}{lccl}
\hline Relationship & $\mathrm{X}^{2}$ & P-value & Remarks \\
\hline Quizzes & 1.33 & 0.5142 & not significant \\
Examination & & & \\
\hline
\end{tabular}

With 0.05 level of significance

\section{Discussion of Results}

4.1. Students' perception towards examination when grouped to announced, immediate and unannounced quizzes

\subsubsection{Students' perception towards examination when grouped to announced quizzes}

Students strongly agree on I like exam when our teacher announced it (item 2), I prefer to have an exam weekly (item 4), and I get high score when there is time for me to prepare for an exam (item 5) as their perception towards examination when grouped to announced quizzes. Giving regular quizzes encourages regular study and better overall performance. With this, quizzes can be used to test students' retention of course materials. It also indicates that quizzes helped students keep up with the course material (Azarlosa and Renner, 2006).

\subsubsection{Students' perception towards examination when grouped to immediate quizzes}

In terms of immediate quizzes, the students strongly agree on an exam at the end of the discussion tests my understanding to the topic discussed. An achievement test given immediately after completing the instruction provides students' the opportunity to review, study and reflect on the instruction before being tested (Airasian, 2005). In the study of Anderson, et al. (1974), quizzing students' immediately after reading a passage enhanced the students' performance one week later. Students' who were quizzed immediately after reading a passage perform better on the test administered a week later than the students' who were quizzed twenty minutes after a passage. It is plausible that decay of memory may play a role in decreasing performance on evaluation administered twenty minutes after the presentation of material. The increased on immediate accountability may also play role in increasing performance.

\subsubsection{Students' perception towards examination when grouped to unannounced quizzes}

Most of the students answered agree on I prefer to have an exam given before another lesson starts (item 2) and I Iike exam related to my assignment (item 4). Unannounced quizzes had impact on students' performance and different subjects, which revealed better learning by the use of unannounced pop quizzes compared to announced quizzes (Kamuche, 2007). The use of unannounced quizzes is especially effective because it is an application of intermittent reinforcement. 
Given the weight on the influence of grades and on students' attendance and study behaviour (Bill, 2001). Unannounced quizzes can be important to students' success. It is believed that unannounced quizzes encourage students to read the material prior to the lectures. The overall result in pre and post assessment was 2.77 and 2.92 which means that students agree on the statements, which implies that the students had a positive perception towards the examination.

4.2. Students' performance in the three modes of quizzes when grouped to announced, immediate and unannounced quizzes

\subsubsection{Students' performance in the three modes of quizzes when grouped to announced quizzes}

Thirty-nine-point fifty eight percent (39.58\%) of the students grouped to announced quizzes got a score between 36-40 which means good. In announced quizzes students gained almost twenty percentage points on the quiz scores when the quizzes were announced and reported and if the students expected the quiz. The study showed that announced quizzes can cause students to study more and it also increased attendance on the dates that the instructor give quizzes (Azarlosa and Renner, 2006). The result implies that students performed good and had a high performance in announced quizzes since all of the students passed and had a better score in this mode of quiz.

\subsubsection{Students' performance in the three modes of quizzes when grouped to immediate quizzes}

Thirty-nine-point fifty eight percent (39.58\%) of the students grouped to immediate quizzes got score between 3135 which means satisfactory. DeRoma et.al.2003, examined students' retention of material based on the timing of quizzes. Students who were given quizzes immediately after a lecture perform better than on a delayed quiz and students' who were given no quiz at all. Students who were quizzed after the lecture through the students were not able to take notes, performed better on the delayed quiz than those who were able to take notes but not quizzed immediately. A quiz administered immediately after the lecture had been proposed as a student-centered technique that might prompt the students to become more actively engaged prior to the quiz. Immediate quizzes increased students' performance and also increases attending lecture.

\subsubsection{Students' performance in the three modes of quizzes when grouped to unannounced quizzes}

Majority (60.42\%) of the students' grouped to unannounced quizzes got scores between 26-30 which means passed. The use of unannounced quizzes is especially effective because it is an intermittent reinforcement given the weight on the influence of grades on students' attendance and study behaviour (Bill, 2001). An unannounced quiz tends to increase the examination tension and stress, and did not offer a fair examination (Graham, 1999). Based from the result, it reveals that among the three modes of quizzes students had the lowest performance obtained in unannounced compared to announced and immediate quizzes. Students' did not like surprise and unannounced quizzes because they were not ready and was not informed by the teacher.

\subsection{Students' achievement score in Environmental Science when grouped to prelim, midterm and final} examination

\subsubsection{Students' achievement score in Environmental Science when grouped to prelim examination}

Fifty percent (50\%) of the students' grouped to prelim examination got achievement scores between 36-40 which means good. Based on the percentage obtained by the students during prelim examination, they got a high score on prelim in which quizzes are given as announced to students and they were informed by the teacher. The impact of student performance on different subjects is better learned by the use of announced pop quizzes (Kamuche, 2007). Graham (1999) showed that average test scores for students who were exposed to announced quizzes were higher than those who were not exposed to announced quizzes.

\subsubsection{Students' achievement score in Environmental Science when grouped to midterm examination}

Thirty-three point thirty three $(33.33 \%)$ of the students' grouped to midterm examination got an achievement scores of between 36-40 which means good. Students during midterm examination had average performance based on the scores they obtained in the midterm examination. Immediate quizzes were given in this period as a mode of quiz to test their understanding right after the discussion before the lesson ends. The procrastination and the students' performance on immediate and delayed quizzes indicate that the students' performance on immediate quiz. 
Although a quiz administered immediately after the lecture has been proposed as a student-centered technique that might prompt the student to become more actively engaged prior to quiz, However, there was no significant difference found among the means of the task behaviour for the immediate, delayed and baseline condition of the study. Thus, the immediate quizzes did not appear to serve as a prompt for the students to attend more to lecture (DeRoma, 2003).

\subsubsection{Students' achievement score in Environmental Science when grouped to final examination}

Thirty-nine-point fifty eight percent $(39.58 \%)$ of the students grouped to final examination got an achievement scores between 26-30 which means passed. Using unannounced quizzes and anonymous quizzes results in deeper levels of understanding and better long-term memory than simply hearing, memorizing or reading about a concept (kamuche, 2006). This implies that during final examination, unannounced quizzes were given and thus, students got a low score compared to the other mode of quizzes which are announced and immediate quizzes.

\subsection{Difference on the students' performance when grouped to three modes of quizzes}

Analysis of variance revealed no significant difference on the students' performance in the three modes of quizzes. Zate (2013) on her study showed that students got high scores on announced compared unannounced and immediate quizzes. This implies that students performed differently in the three modes of quizzes and among the three modes, they performed better on announced quizzes. Graham (1999) showed that average test scores for students who were exposed to announced quizzes were higher than those who were not exposed to announced quizzes. Multiple quizzes are reasonable extrinsic motivators for learning. Giving regular quizzes encourages regular study and better overall performance. With this, quizzes can be used to test students' retention of course materials. It also indicates that quizzes helped students to keep up with the course material (Azarlosa and Renner, 2006).

\subsection{Relationship between the students' perception towards examination and performance in the three modes of quizzes}

Chi-square test result revealed significant relationship on the students' perception towards examination and their performance in three modes of quizzes Based on the scores they obtained during quizzes and the response on perception questionnaire, it was found out that their perception towards examination and their performance in the three modes of quizzes are related to one another. Stromses (2001) examined the effect of three different quizzes contingencies that varied in terms of the number of quizzes and examinations that student took during the semester. It was concluded that grade-related contingencies mean high overall attendance.

\subsection{Relationship on the students' performance in three modes of quizzes and achievement score in Environmental Science}

There was no significant relationship on the students' performance in three modes of quizzes and their achievement scores in Environmental Science. According to Azarlosa (2006), quizzing caused the students to study. Quizzes helped the students to keep up with the course material. Quizzes also encourage them to read the material prior to the lecture so that comprehension of the lecture will be enhanced (Solomon, 1979).

\section{Summary and Conclusions}

1. This study dealt on the relationship on the perception towards examination and students' performance in the three modes of quizzes. It also sought to find out the significant relationship on the students' perception towards examination and their performance on the three modes of quizzes. The subject respondents of the study were the 48 education students who were enrolled in EdSc 140 of Mindanao State University at Naawan. The study used survey questionnaires on the perception towards examination, and test questionnaires. This study utilized a quantitative descriptive correlation research design. Data were analyzed and organized through percentage, mean, anova and chi-square test.

2. Students strongly agree on I like examination when the teacher announced it (item 2), I prefer to have an examination weekly (item 4), and I get high scores when there is time for me to prepare the exam (item 5). In terms of immediate quizzes, students strongly agree on an examination at the end of the discussion test my understanding on the topic discussed (item 3). In terms of unannounced quizzes, students agree on I prefer to have an examination given the day before another lesson starts (item 2) and I like the examination related to my assignments (item 4). 
3. Forty percent (40\%) of the students when grouped to announced quizzes got a score between $36-40$ which means good, forty percent $(40 \%)$ of them when grouped to immediate quizzes got scores between 31-35 which means satisfactory, sixty percent $(60 \%)$ of them when grouped to unannounced quizzes got scores between 26-30 which means passed.

4. Forty percent (40\%) of the students got achievement scores in prelim examination between $36-40$ which means good, thirty three percent $(33 \%)$ of them got scores in midterm examination between 31-40 which means good and forty percent $(40 \%)$ of them had scores between 26-30 which means passed in their final examination.

5. Analysis of variance showed that there was a significant difference on the students' performance in the three modes of quizzes.

6. Chi-square test result showed a significant relationship between the student's perception towards examination and their performance in three modes of quizzes.

7. There was no significant relationship between the students' performance in the three modes of quizzes and their achievement scores in Environmental Science.

8. This study concluded that perception towards examination can affect the students' performance in the three modes of quizzes.

\section{Implications and Recommendations}

1. The study implies that students performed better in announced compared to unannounced and immediate quizzes. They like quizzes that are scheduled and when there is ample time given for them to prepare.

2. Teachers may give quizzes that can be announced, unannounced and immediate to measure different performance of students. Since, there are students who are good when there is time for them to prepare. There are also students who are very attentive and listen well to their teacher and performed better when quizzes are given right after the discussion.

3. Three modes of quizzes can also be administered to other subjects, especially mathematics to test if students really listen and study well the subject.

4. A comparison of these three modes of quizzes can be done with the use of different strategies and correlate it to their performance.

5. They may include the gender differences of students to find out which mode of quiz does a male and female performed better.

\section{Acknowledgment}

The author is very grateful to the Almighty Father for all the blessings He showered upon him. For giving the strength, wisdom, courage, guidance and good health to make this paper a successful one. The author gives back all the Glory and Honor through His son Jesus Christ.

The author would also extend his deepest and sincerest thanks to the following persons who in one way or another contributed to this manuscript;

His ever-supportive parents mama Marivic C. Alia, itayLeodegario C. Alia Jr., and siblings kuya "Gedong" and ate "Pik2x", for the constant undying love, care, encouragement and unending moral support who pushes him to finish this paper;

$\mathrm{He}$ is also intensely grateful to Marjorie M. Gonzales for the judicious support in editing the format, for the encouragement, strength and unconditional love;

Dr. Arlene C. Dolotallas, his thesis adviser for sharing her expertise, time, constructive criticism and great support which had contributed a lot to this manuscript;

Bella C. Mugot, thesis examiner, for her support, encouragement, valuable pieces of advice and guidance and for deeply scrutinizing to enhance this paper;

Ruth E. Moleño, his thesis examiner, for the necessary corrections, encouragement and guidance which contributed a lot to this study;

Bella S. Amarga, DSEE Chairperson for facilitating the author for the conduct of the study;

Guilbert A. Cabillan, his statistician for the nerve wracking and mind-boggling activities in analyzing the data; Dr. Jessie G. Gorospe, Vice Chancellor for Academic Affairs for his moral support and encouragement to pursue this study;

EdSc 140 students for the cooperation extended as the respondents of the study; 
The squad members, Kristine "Tina”, Cyrus "King2x",JunAlvasir "Halap",Mary Grace "Grasya", Rosedel "madam", Marjorie "Baby", ma'am Eden and sir Fernan for the laughter and bonding moments and;

A sincerest appreciation is also given to his friends, relatives, colleagues, and teachers for the support and ideas they have shared in this paper.

\section{References}

Alia, L.C and H, M.Manait. 2013. Performance of Grade Seven Students in Three Modes of Quiz: A comparative Study: Undergraduate Thesis. Iligan City: Mindanao State University-Iligan Institute of Technology.

Airasian P.W. 2005.Classroom Assessment: key Concepts and Applications. Fifth Edition

Anderson R.C., J.Surber, B.M Biddle. P.M Zynch, P.M and C.E Lieberman. 1997.Retention of Text Information As a Function of the Nature, Timing and Number of Quizzes. Urbana, IL: University of Illinois at Urbana Champaign. (Eric Document Reproduction Service no. ED08 9200).

Bell, John T. 1997. Anonymous Quizzes: An effective feedback mechanism. Chemical Enginering Education, vol. 31, no.1, (winter): 56-57.

Azarlosa, J.L and C, H. Penner. 2006. The effects of Announced Quizzes on Exam Performance.Journal of Psychology, Department of Psychology.West.

Del Socorro. F.M., R.SGalela.G.BOmas-as. 2011. Assessment of Student Learning 1 and 2. Phoenix Publishing, Quezon City.

DeRoma, V. ., A. Young, S.T. Mambrouk, K.P. Brannan, R.O. Hilleke, K.Y. Johnson.2003. Procastination and student's performance on immediate and delayed quiz.

Graham, R.B. 1991. Unannounced quizzes raise test scores selectively for mi-range students. Prentice-Hall, Inc., Englewood Cliffs, New Jersey 07632.

Kamuche, F. U. 2007. Effects of Unannounced and announced quizzes on students' performance. Vol.3.,No.2 College Teaching Methods and Styles Journal. Morehouse College. Retrieved on December 23.2009. http://www.cluteinstitutejournal.com

Kallick, Ben and James Wilson III (2001). InformationTechnology for Schools California. Jossey-Boss Inc. pp.33-42.

Santos, R. DG, Ph.D. 2007.Assessment of Learning 1. Lorimar Publishing Inc, 776 Aurora Blvd., cor.Boston Street, Cubao, Quezon City.

Stromses, W. 2001. The use of random extra credit quizzes to increase student's attendance. George Uhlig Publisher.

Zate, Conielyn R. "Achievement Scores of Students in Three Modes of Quiz in Biology in Mindanao State University at Naawan-Integrated Developmental School, S.Y. 2010- 2011". April 2011. Undergraduate Thesis,BSE -Biology,College of Education and Social Sciences, Mindanao State University at Naawan ,Misamis Oriental. 